\title{
Dedifferentiation of conditionally immortalized hepatocytes with long-term in vitro passage
}

\author{
Byung-Ho Kim ${ }^{1,2}$, Se-Ra Sung ${ }^{1}$, Eun-Hee Choi ${ }^{1}$, \\ Young-IL Kim ${ }^{1}$, Kyeong-Jin Kim ${ }^{1}$, \\ Seok-Ho Dong', Hyo-Jong Kim ${ }^{1}$, \\ Young-Woon Chang ${ }^{1}$, Joung-II Lee ${ }^{1}$ \\ and Rin Chang ${ }^{1}$ \\ ${ }^{1}$ Department of Internal Medicine, Kyung Hee University College of \\ Medicine, Seoul 130-702, Korea \\ ${ }^{2}$ Corresponding author: Tel, 82-2-958-8145; Fax, 82-2-968-1848; \\ E-mail, kimbh@khmc.or.kr
}

Accepted 23 February 2000

Abbreviations: $\mathrm{CIH}$, conditionally immortalized hepatocytes; FCS, fetal calf serum; PDT, population doubling time; SV40, simian virus 40; TRAP, telomerase repeat amplification protocol; tsT, temperature-sensitive (mutant of) SV40 large T antigen.

\begin{abstract}
The rat hepatocytes were immortalized using a temperature-sensitive mutant of SV40 large T antigen (tsT) to develop as a possible substitute for primary hepatocytes. Four rat hepatocyte lines that have been developed and maintained more than passage 50 , were characterized for their cellular morphology, $\mathrm{T}$ antigen and p53 expression, chromosomes, liverspecific differentiation, telomerase activity and anchorage independent growth. All of four cell lines showed a typical epithelial cell morphology, but the population-doubling time became short with passage: 18 to $60 \%$. T antigen expression was increased with passage about 3 to 65 times at permissive temperature but decreased significantly at non-permissive temperature. The expression level of p53 unchanged during passages was also decreased at non-permissive temperature. The distribution of chromosome number changed somewhat with passage. The production levels of albumin and urea in four cell lines were 2.4 to $13.0 \%$ and 7.5 to $19.9 \%$ of those produced in primary hepatocytes, respectively and were decreased to an undetectable level with passage. Telomerase activity was increased 10 fold following immortalization of cells, but anchorage independent growth of cells did not develop. These results indicate that conditionally immortalized hepatocytes become dedifferentiated with in vitro passage, which may be caused by marked chromosomal
\end{abstract}

damages that occur with compulsive and continuous replications by the increment of $T$ antigen content with passage and its sequential inhibition of p53 function.

Keywords: chromosome, conditional immortalization, liverspecific differentiation, Rat hepatocytes, temperature-sensitive SV40 large T antigen, telomerase

\section{Introduction}

Primary hepatocytes have extensively been used to investigate mechanisms of cell growth and differentiation, metabolic processes, biotransformation and genotoxicity of drug, carcinogenesis, and ex vivo gene therapy. Transplantation of hepatocytes has also been applied in clinical trials for bioartificial liver. However, the transcription ability of liver specific genes decreases dramatically when hepatocytes are removed from an animal and cultured in vitro (Clayton et al., 1983; Guguen-Guillouzo et al., 1983a). Such rapid dedifferentiation was partially overcome by culturing the cells in a hormonally defined medium on an extracellular matrix (Rojkind et al., 1980; Dich et al., 1988; Waxman et al., 1990) or coculturing them with non-parenchymal liver cells (Guguen-Guillouzo et al., 1983b; Morin et al., 1986). Tumor cell lines that retain functional capabiliity of liver cells and grow in culture have been tried (Brown et al., 1979). However, cell transformation may partially abrogate cell-specific transcription (Clayton et al., 1985). The conditionally immortalized hepatocytes $(\mathrm{ClH})$ with a gene for tsT or tumor cell lines have been employed to investigate mechanism of hepatocyte-specific differentiation (Chou, 1983; Jat et al., 1989; Fox et al., 1995) or to treat liver failure (Schumacher et al., 1996; Nakamura et al., 1997). ClH may be a good alternative, because they can be cultured almost indefinitely at permissive temperature $\left(33^{\circ} \mathrm{C}\right)$ and grown into a large cell mass. Moreover, they become differentiated on culturing them at non-permissive temperature $\left(37-39^{\circ} \mathrm{C}\right)$, which is similar to body temperature. Here, we report the change of liver-specific differentiation in $4 \mathrm{ClH}$ lines that were established from two rat strains and describe a possible mechanism of differentiation change with in vitro passage.

\section{Materials and Methods}

Animals 
Wistar and Brown-Norway rats (150-250 g) were purchased from Charles River, Japan and maintained on standard laboratory chow on a $12 \mathrm{~h}$ light/dark cycle in the Animal Resource Facility of the Kyung Hee University Hospital, Seoul, Korea. Experimental procedures were approved by an Institutional Animal Care and Use Committee of Kyung Hee University College of Medicine under the guidelines provided for humane care of laboratory animals.

\section{Recombinant retrovirus expressing ts $\mathrm{T}$}

A $\varphi-2$ derived producer cell line for an ecotropic recombinant retrovirus (early region mutant tsA58) containing the genes encoding tsT and neomycin phosphotransferase was kindly provided by Dr. P.S. Jat, the Ludwig Institute for Cancer Research, London, U.K. This producer cell line provides a viral titer of $5 \times 10^{4}$ neomycinresistant colony-forming units/ml when assayed on $\mathrm{NIH}$ 3T3 cells (Jat et al., 1989).

Supernatant, containing the recombinant retrovirus, was harvested from subconfluent culture plates of producer cells $18 \mathrm{~h}$ after the addition of fresh medium, filtered through $0.45 \mu \mathrm{m}$ filters, and frozen at $-70^{\circ} \mathrm{C}$ until its use as the source of infection for conditional immortalization.

\section{Isolation and conditional immortalization of hepato- cytes}

Hepatocytes were isolated by a modified two-step in situ collagenase (Boehringer-Manheim, Indianapolis, IN, USA) perfusion (Seglen, 1973). Viability of the isolated cells, as determined by trypan blue exclusion, was more than $90 \%$. The cells were suspended in $\alpha$-MEM (Gibco BRL, Grand Island, NY, USA) containing $10 \%$ fetal calf serum (FCS) and $0.2 \mu \mathrm{mol} / \mathrm{L}$ dexamethasone (Sigma Chemical Co., St. Louis, MO, USA), and plated at a density of 4 $\times 10^{6}$ cells $/ 10 \mathrm{~cm}$ culture dish. After a $4 \mathrm{~h}$ attachment, the culture was incubated at $37^{\circ} \mathrm{C}$ in a $95 \%$ air $/ 5 \% \mathrm{CO}_{2}$ atmosphere overnight with a change to fresh medium. Hepatocytes were infected $24 \mathrm{~h}$ after the establishment of culture with a $4 \mathrm{ml}$ viral stock per plate in the presence of $8 \mu \mathrm{m} / \mathrm{ml}$ polybrene (Aldrich Chemical Co., Milwaukee, WI, USA) at $37^{\circ} \mathrm{C}$ for $4 \mathrm{~h}$. The virus-containing medium then was aspirated, and cultures were maintained in $\alpha$-MEM containing $4 \% \mathrm{FCS}$ and $0.2 \mu \mathrm{mol} /$ I dexamethasone at $33^{\circ} \mathrm{C}$. Mock-infected cell culture was also performed with the same method except for supernatant without the retrovirus. Four days later, neomycinresistant hepatocytes were selected by adding the neomycin analogue G418 (Sigma) at $400 \mu \mathrm{g} / \mathrm{ml}$. G418resistant colonies were isolated using the cloning cylinder, released by trypsinization and expanded by culturing at $33^{\circ} \mathrm{C}$.

\section{The change of growth rate and chromosomes with in vitro passage}

The cells were maintained in $10 \mathrm{~cm}$ culture dishes and fed fresh $\alpha$-MEM containing $4 \%$ FCS and $0.2 \mu \mathrm{mol} / /$ dexamethasone twice weekly. When cultures became confluent, the cells were trypsinized and sub-cultured at a dilution of $1: 3$ in $\alpha$-MEM containing $10 \%$ FCS to aid cell attachment. The culture was maintained for more than 50 passages. The change in morphology, rate of growth and chromosomes were examined at lower (between passages 10 to 20, with cell division of around 50 times) and higher passage (over passages 50 , with cell division of more than 100 times). In order to determine the growth rate, the cells were plated at a density of $5 \times 10^{4}$ cells per $10 \mathrm{~cm}$ plate and incubated at $33^{\circ} \mathrm{C}$ for up to 10 days, and then the temperature of culture was changed to $39^{\circ} \mathrm{C}$ which was maintained for another 5-7 days. With 1 to 3 day intervals, cells were released with trypsin and counted from 3 plates, respectively, and the population doubling time (PDT) of each cell line was calculated. Chromosomes were prepared according to the standard procedure. The cells were incubated with colcemid $(10 \mu \mathrm{g} / \mathrm{ml})$ for $3 \mathrm{~h}$, then lyzed with $0.075 \mathrm{M} \mathrm{KCl}$ for $8 \mathrm{~min}$ and fixed with methanol/acetic acid ( $\mathrm{v} / \mathrm{v}, 3: 1)$. Chromosomal preparations were stained with Giemsa. One hundred cells were used to count the chromosome number.

\section{Expression of $\mathrm{T}$ antigen and p53 content}

To determine the $T$ antigen or p53 protein content, the cells were cultured at $33^{\circ} \mathrm{C}$ and $39^{\circ} \mathrm{C}$ for 2 days and used in Western blot analysis. COS-7 and A 431 were used as positive controls for $T$ antigen and p53, respectively, and primary hepatocytes were used as a biologic negative control. Cell homogenates $(20 \mu \mathrm{g}$ for $\mathrm{T}$ antigen, $50 \mu \mathrm{g}$ for p53) were subjected to SDS-polyacrylamide gel (7.5\% for $\mathrm{T}$ antigen, $10 \%$ for p53) electrophoresis and electroblotted to polyvinylidene difluoride membrane (Millipore Corp., Bedford, MA, USA). Immunotransblot was performed using mouse monoclonal antibodies against T antigen and p53 (500 times dilution, Oncogene Science, Cambridge, MA, USA) and peroxidase-conjugated sheep anti-mouse IgG antibody (3000 times dilution, Amersham, Buckinghamshire, England). The proper bands were detected with chemoluminescent substrates ( $E C L^{\mathrm{TM}}$ Kit, Amersham, Buckinghamshire, England).

In order to analyze whether T antigen is bound to p53, immunoprecipitation analysis was performed. Cell lysates (200 $\mu \mathrm{g}$ total protein) were precleaned with $1 \mu \mathrm{g}$ rabbit anti-mouse IgG followed by precipitation with $30 \mu \mathrm{l}$ of $10 \%$ formalin-fixed Steph A cells (Sigma). Lysates were incubated with anti-SV40 large $T$ antigen mouse monoclonal antibody followed by incubation with rabbit antimouse IgG antiserum and precipitated with Steph A cells. After washing 3 times with lysis buffer, the bound proteins were released by heating at $85^{\circ} \mathrm{C}$ for $10 \mathrm{~min}$ in SDS-PAGE sample buffer containing $62.5 \mathrm{mM}$ Tris- $\mathrm{Cl}$ 
(pH 6.8), $2.5 \%$ SDS, $10 \%$ glycerol and $0.02 \%$ bromophenol blue. After electrophoresis, immunotransblot assay was performed using anti-p53 mouse antibody as previously described.

\section{Analysis of liver-specific differentiation}

The rate of albumin secretion was calculated by a competitive inhibition ELISA (Kowalski-Saunders et al., 1992). For this purpose, the cells were cultured on plates coated with vitrogen (Collagen Corporation, Fremont, CA, USA) in modified Chees medium (GibcoBRL formula 96-5205 EP) supplemented with transferrin $(6.25 \mu \mathrm{g} / \mathrm{ml})$, selenium $(6.25 \mathrm{ng} / \mathrm{ml})$, insulin $(6.25 \mathrm{ng} / \mathrm{ml})$ and dexamethasone $0.2 \mathrm{ng} / \mathrm{ml}$ (Waxman et al., 1990). When the cells were grown at $33^{\circ} \mathrm{C}$ up to $70 \%$ confluence, one set of plates was moved to a $\mathrm{CO}_{2}$ incubator at $37^{\circ} \mathrm{C}$ and maintained for 2 days. Primary rat hepatocytes were used as a positive control. Briefly, rat albumin (Sigma) in $0.05 \mathrm{~mol} /$ I carbonate/bicarbonate buffer, $\mathrm{pH}$ 9.5, was coated on Costar Immuno ELISA plates (25 ng/well, Corning), incubated overnight at $4^{\circ} \mathrm{C}$, and designated coated plates. Equal volumes of a goat anti-rat albumin (1:500 dilution, ICN Pharmaceuticals Inc., Aurora, OH, USA) and culture supernatant or standard concentrations of rat albumin in diluting buffer (PBS with 0.05\% Tween-20 and $2 \mathrm{mg} / \mathrm{ml}$ of bovine serum albumin) were incubated overnight at $4^{\circ} \mathrm{C}$. One hundred microliters of reaction mixture was transferred sequentially to the coated plates and incubated for $1 \mathrm{~h}$ at room temperature. After washing three times with a diluting buffer, they were incubated with a peroxidase-conjugated rabbit anti-goat immunoglobulin (1:10,000 dilution, ICN Pharmaceuticals Inc.) for $1 \mathrm{~h}$ at room temperature. The color was developed with an addition of $o$-phenylenediamine $(0.04 \% \mathrm{w} / \mathrm{v}$, Sigma). After stopping the reaction with $1 \mathrm{M} \mathrm{H}_{2} \mathrm{SO}_{4}, \mathrm{~A}_{492}$ was determined. The rate of urea synthesis from ammonium chloride was determined with the Sigma Urea Kit No. 553-B (Sigma). The cells were incubated in the media with 10 $\mathrm{mM}$ ammonium chloride under the same condition as described previously. After a $2 \mathrm{~h}$ incubation, the concentration was measured according to the instruction manual. The rate of albumin and urea production was expressed as the total amount of albumin and urea secreted from one million cells during $24 \mathrm{~h}$ and $1 \mathrm{~h}$, respectively.

\section{Telomerase activity}

Telomerase activity was measured by telomerase repeat amplification protocol (TRAP) assay (Kim et al., 1994) using a commercial kit (TRAPeze ${ }^{\mathrm{TM}}$, Intergen Company, Purchase, NY, USA). Briefly, cell extracts were prepared by lysing the cells in $1 \times$ CHAPS extraction buffer $\left(10^{6}\right.$ cells $/ 200 \mu \mathrm{l})$, and $2 \mu \mathrm{g}$ of primary hepatocytes and 0.2 $\mu \mathrm{g}$ of immortalized cells were used in assay.

The telomerase reaction was performed in $50 \mu \mathrm{l}$ of

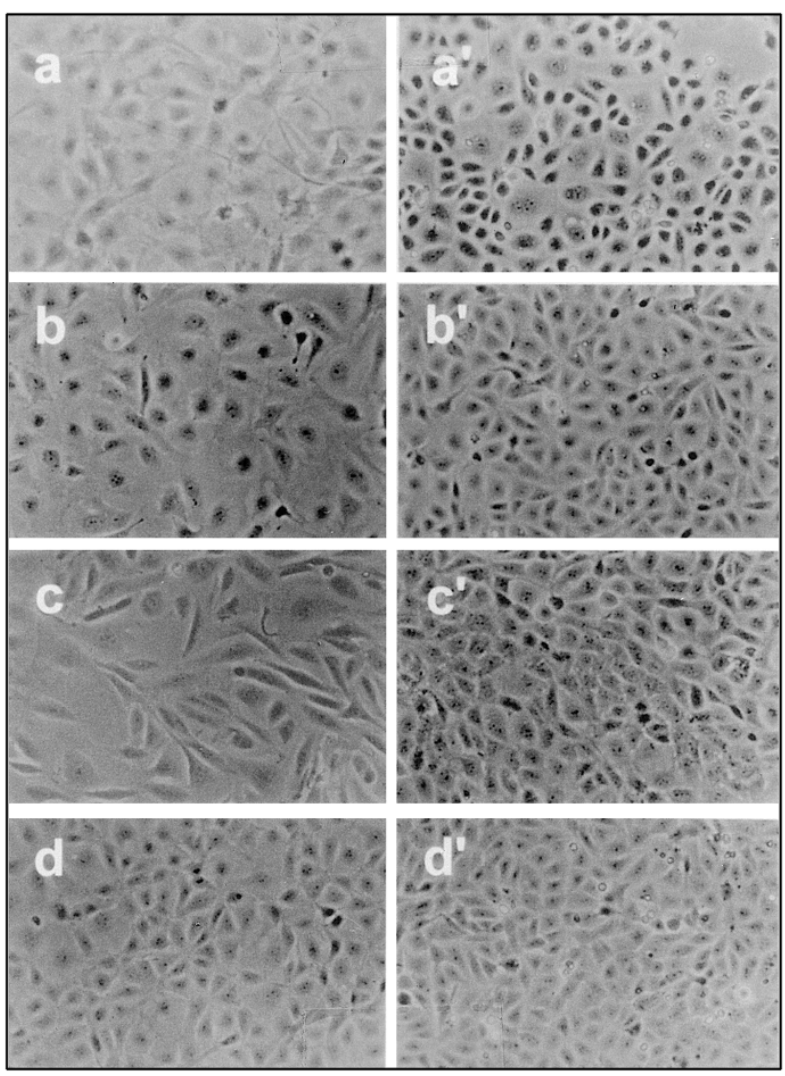

Figure 1. The morphology of four immortalized hepatocyte lines. The cells show polygonal shapes with central nuclei and abundant cytoplasm, which suggest that they originate from epithelial cells (a, WA1; b, WB6; c, BQ1; $d$, BV1; a',b',c' and d', higer passage of each cell lines). Phase contrast microscopy $\times 100$.

TRAP buffer containing $20 \mathrm{mmol} / \mathrm{Tris}-\mathrm{HCl}(\mathrm{pH} 8.3), 1.5$ $\mathrm{mmol} / \mathrm{l} \mathrm{MgCl}, 63 \mathrm{mmo} / / \mathrm{KCL}, 0.005 \%$ Tween-20, $1 \mathrm{mmol} /$ I EGTA, $0.01 \%$ bovine serum albumin, $50 \mu \mathrm{mol} / \mathrm{l} \mathrm{dNTPs}$, internal control primers (RP and K1 primers, TSK1 template), $5 \mathrm{U}$ of Taq polymerase and $\gamma^{32} \mathrm{P}$ labeled TS primer (5'-AATCCGTCGAGCAGAGTT-3'). Reaction tubes were placed in a thermocycler (Perkin-Elmer 9600, USA) for $30 \mathrm{~min}$ at $30^{\circ} \mathrm{C}$, followed by 32 cycles of polymerase chain reaction at $94^{\circ} \mathrm{C}$ for $30 \mathrm{~s}, 56^{\circ} \mathrm{C}$ for $30 \mathrm{~s}$ and $72^{\circ} \mathrm{C}$ for $30 \mathrm{~s}$. One half of the amplified products were resolved on a $12.5 \%$ non-denaturing polyacrylamide gel in $0.5 \times$ TBE buffer, dried, and visualized by autoradiography after 2 to $4 \mathrm{~h}$ exposure at room temperature. For a valid analysis of the TRAP assay data, internal PCR amplification control, heat-inactivated control, biologic telomerase positive control (KATO III cells) and primer-dimer/PCR contamination control were also used.

\section{Anchorage independent growth}

Anchorage independent growth property in soft agar assay was analyzed to evaluate the possibility of oncogenicity 

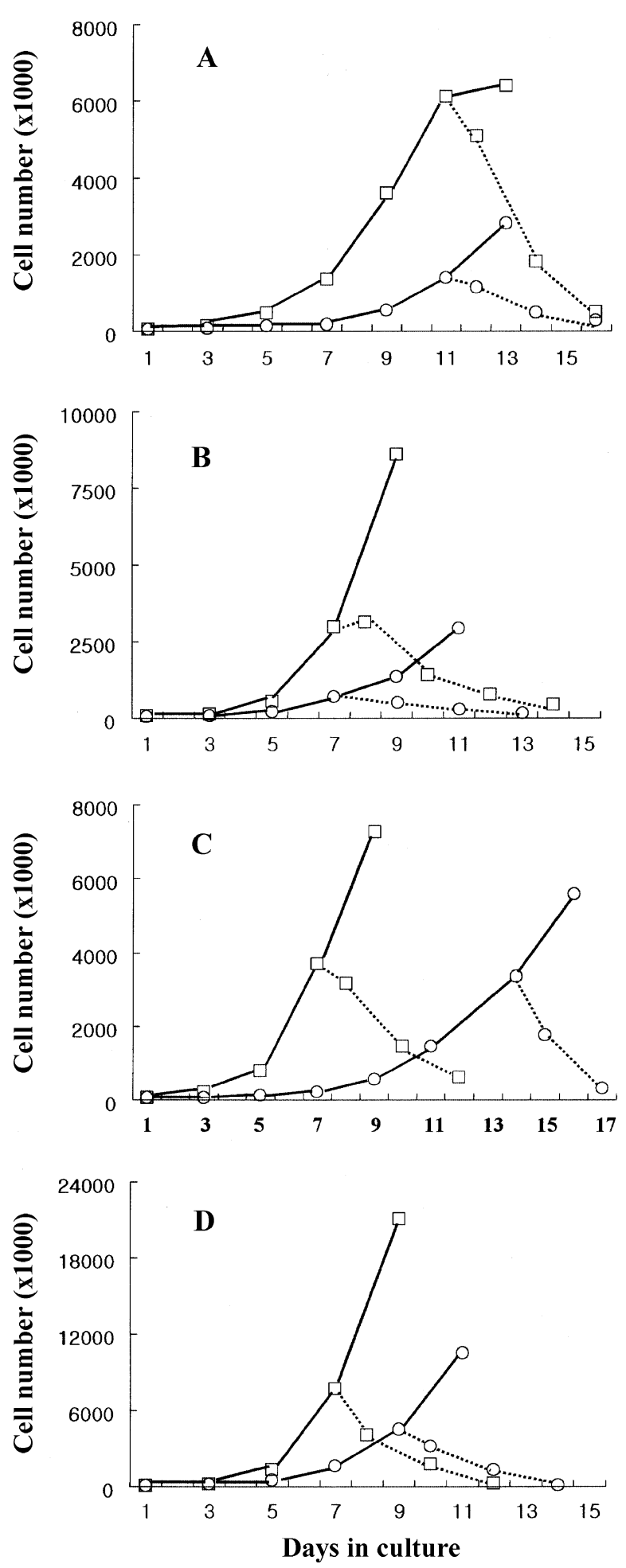

Figure 2. The growth characteristics of immortalized hepatocyte lines. Four cell lines proliferate exponentially at $33^{\circ} \mathrm{C}$ but stop growing and undergo cell death at $39^{\circ} \mathrm{C}$, which suggest that they maintain temperature-sensitivity. Although the growth rate of each cell line is different, it definitely accelerates with passage in all cell lines. A, WA1; B, WB6; C, BQ1; D, BV1; open circle, the cells with lower passage; open square, the cells with higher passage; solid line, culture at $33^{\circ} \mathrm{C}$; broken line, culture at $39^{\circ} \mathrm{C}$.
Table 1. The change of population doubling time in four immortalized hepatocyte lines with in vitro passage

\begin{tabular}{cccc}
\hline Cell line & $\begin{array}{c}\text { Passage 15 } \\
(\mathrm{h})\end{array}$ & $\begin{array}{c}\text { Passage 50 } \\
(\mathrm{h})\end{array}$ & \% Shortening \\
\hline WA1 & 42.2 & 30.8 & $27.0 \%$ \\
WB6 & 28.7 & 23.5 & $18.2 \%$ \\
BQ1 & 59.3 & 23.7 & $60.0 \%$ \\
BV1 & 33.4 & 17.8 & $46.7 \%$ \\
\hline
\end{tabular}

The PDT was calculated from the mean growth rate.

of the cells (Macpherson et al., 1964). Cultures were prepared as follows; a base layer of $3 \mathrm{ml}$ of medium containing $0.6 \%$ Noble agar (Difco Lab., Detroit, MI, USA) was set in $6 \mathrm{~cm}$ petri dishes before the addition of a second layer with $5 \times 10^{4}$ cells in $3 \mathrm{ml}$ of medium containing $0.3 \%$ agar. The plates were incubated at $33^{\circ} \mathrm{C}$ in a humidified atmosphere of $5 \% \mathrm{CO}_{2}$ in air. Plates were fed up with $1.5 \mathrm{ml}$ of medium containing $0.3 \%$ agar twice weekly and maintained up to 4 weeks. Colonies from unstained cultures were counted under a low power microscope. A differentiated human hepatoma cell line (Hep G2) was served as a positive control.

\section{Statistics}

Values are expressed as mean \pm SD. Statistical differences were determined by Students $t$ test. A $p$-value $<0.05$ was considered to be significant.

\section{Results}

Four clones (WA1 and WB6 from a Wistar rat, BQ1 and BV1 from a Brown-Norway rat) could be expanded up to more than passage 50 and subjected to further examinations.

\section{The change of morphology and growth rate with in vitro passage}

All four immortalized cell lines showed a polygonal shape with the central location of the nucleus and abundant cytoplasm (Figure 1).

At $33^{\circ} \mathrm{C}$, all four cell lines proliferated exponentially and the change of incubation temperature to $39^{\circ} \mathrm{C}$ caused a rapid decrease in cell proliferation (Figure 2). The PDT of each cell lines with lower passage was 42.2, 28.7, $59.3,33.4 \mathrm{~h}$, respectively, and the growth rate definitely accelerated about 18 to $60 \%$ with passage, that is, 30.8 , 23.5, 23.7, $17.8 \mathrm{~h}$ in each cell lines with higher passage (Table 1).

\section{Expression of $\mathrm{T}$ antigen and $\mathrm{p} 53$ content}

$\mathrm{T}$ antigen expressed at $33^{\circ} \mathrm{C}$ was decreased significantly or disappeared at $39^{\circ} \mathrm{C}$. The amount of $\mathrm{T}$ antigen 
A $\begin{array}{llllllllll}1 & 2 & 3 & 4 & 5 & 6 & 7 & 8 & 9 & 10\end{array}$

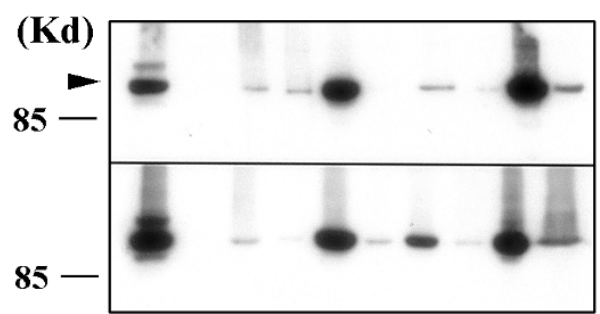

B

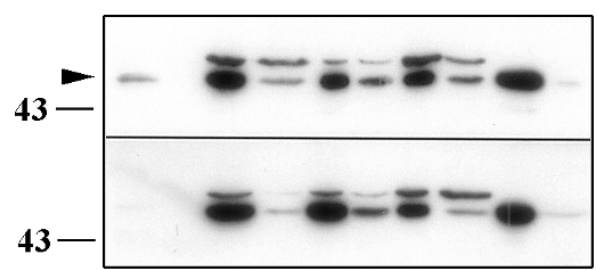

Figure 3. The expression of SV40 large T antigen and p53 in immortalized hepatocyte lines. T antigen that is expressed at $33^{\circ} \mathrm{C}$ decrease significantly at $39^{\circ} \mathrm{C}$ in all cell lines, and the amount of T antigen content in WA1, WB6, BQ1 and BV1 with higher passage increases about 65, 37, 42 and 3 times, respectively, than those in cell lines with lower passage (A). Lane 1, COS as a positive control; lane 2, primary hepatocytes as a negative control; lane 3 and 4, passage 15 of WA1 (upper) and BQ1 (lower); lane 5 and 6, passage 55 of WA1 (upper) and BQ1 (lower); lane 7 and 8, passage 15 of WB6 (upper) and BV1 (lower); lane 9 and10, passage 55 of WB6 (upper) and BV1 (lower); lane 3, 5, 7 and 9, $33^{\circ} \mathrm{C}$; lane 4, 6, 8 and 10, 39 ${ }^{\circ} \mathrm{C}$. p53 also decreases significantly after an overnight incubation at $39^{\circ} \mathrm{C}$ in all cell lines, but the amount does not change with passage (B). The pattern of p53 expression is similar to that of $\mathrm{T}$ antigen except for their amount, which may be resulted from the inhibition of natural p53 breakdown by $T$ antigen binding. Lane 1 is A431 as a positive control, and the other lanes are the same as those of picture $A$.

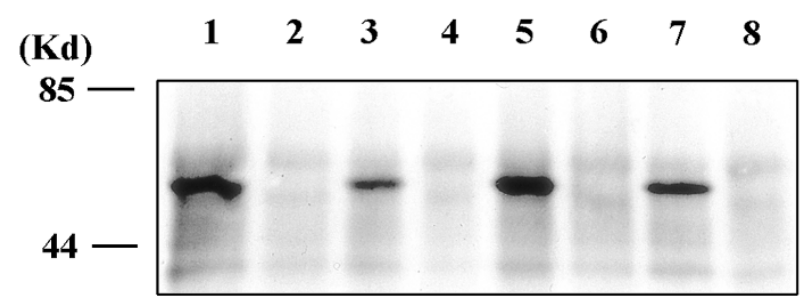

Figure 4. Immunoprecipitation of p53. First, the proteins were precipitated with monoclonal antibody against $\mathrm{T}$ antigen, then immunotransblot was done using anti-p53 antibody. p53 bands were noted only in cells that were cultured at permissive temperature. Lane $1 \& 2$, WA 1 at $33^{\circ} \mathrm{C}$ and $39^{\circ} \mathrm{C}$; lane $3 \& 4$, WB6 at $33^{\circ} \mathrm{C}$ and $39^{\circ} \mathrm{C}$; lane $5 \& 6, \mathrm{BQ} 1$ at $33^{\circ} \mathrm{C}$ and $39^{\circ} \mathrm{C}$; lane $7 \& 8, \mathrm{BV} 1$ at $33^{\circ} \mathrm{C}$ and $39^{\circ} \mathrm{C}$, respectively.

content in cells with higher passages (WA1, WB6, BQ1 and BV1) increased 65, 37, 42 and 3 times, respectively, than those with lower passages (Figure 3, upper panel). The expression of p53 also decreased significantly in all of four cell lines after an overnight incubation at $39^{\circ} \mathrm{C}$, but the amount was not changed with passages (Figure 3 , lower panel). The immunoprecipitation with an antibody against $T$ antigen revealed that $p 53$ was bound to $\mathrm{T}$ antigen at permissive temperature, but not at nonpermissive temperature (Figure 4).
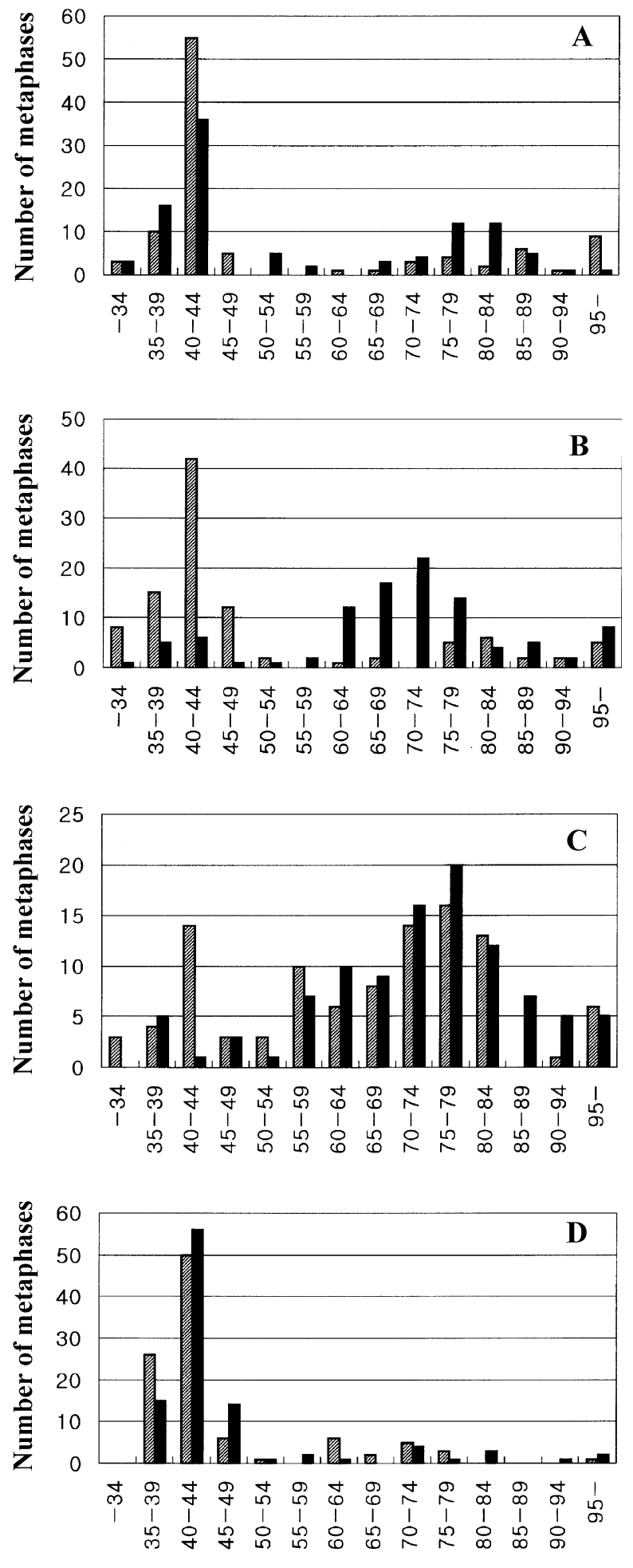

Number of chromosomes

Figure 5. The distribution of chromosome count in immortalized hepatocyte lines. The proportion of tetraploid increased significantly in WA1 (A), WB6 (B), BQ1 (C). Although BV1 did not show a significant change in chromosome count, they showed several common aberrations in higher passage (D, refer to Figure 6). Oblique line and black bars mean each cell line with lower and higher passage, respectively. 

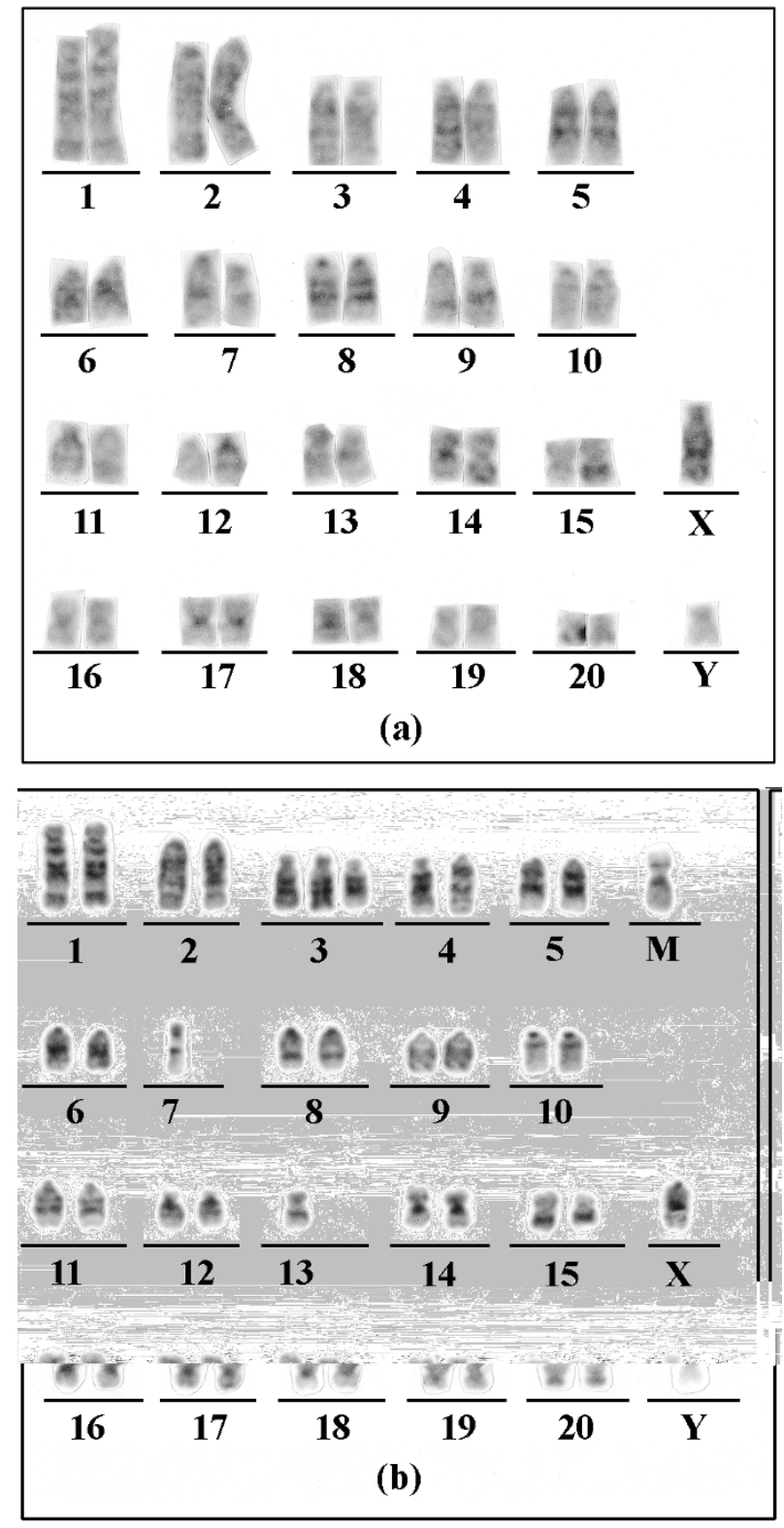

Figure 6. Chromosomal aberrations of an immortalized hepatocyte line, BV1. Although there was no significant change of chromosome count between passage 19 and 52 of BV1, several common chromosomal aberrations were noted only in higher passage. Passage 19 had normal 20 pairs with $X$ and $Y$ chromosome (a), but passage 52 showed a trisomy 3 , a monosomy 7 and 13 , and an unknown marker chromosome (M), repeatedly (b).

\section{The change of chromosome count and morphology after immortalization}

Among four cell lines, WA1, WB6 and BQ1 showed a significant increase of tetraploid along with passage. The proportion of diploid and tetraploid in lower and higher passage changed from $67 \%$ and $16 \%$ to $54 \%$ and $36 \%$ in WA1, from $62 \%$ and $14 \%$ to $11 \%$ and $50 \%$ in WB6, from $19 \%$ and $48 \%$ to $7 \%$ and $61 \%$ in BQ1, respectively (Figure 5). Although there was no significant change of chromosome count between passage 19 and 52 of BV1, several common aberrations of chromosome were noted only in higher passage. Passage 19 showed normal 20 pairs with $X$ and $Y$ chromosome, but passage 52 showed a trisomy 3 , a monosomy 7 and 13 , and an unknown marker chromosome, repeatedly, which were common in 12 cells with earlier passage and 15 cells with higher passage, respectively (Figure 6).

\section{Liver-specific differentiation}

The amount of albumin secreted from primary rat hepatocytes was $30.4 \pm 7.9 \mu \mathrm{g} / 24 \mathrm{~h} / 10^{6}$ cells (Table 2 ). In four immortalized cell lines, the amount of albumin was about 2.4 to $13.0 \%$ of primary hepatoyctes when the cells were cultured at $37^{\circ} \mathrm{C}$ for 2 days, which was about 1.3 to 3.6 times higher than cells cultured at $33^{\circ} \mathrm{C}$. Moreover, the level of albumin secretion decreased approximately $29 \%$ to $61 \%$ with in vitro passage in three cell lines, namely WA1, BQ1 and BV1 but it was low initially in WB6. Production of urea from ammonium chloride in normal rat hepatocytes was $67.3 \pm 22.9 \mu \mathrm{g} / \mathrm{h} / 10^{6}$ cells. In four immortalized cell lines, it was about 7.5 to $19.9 \%$ of that of primary hepatocytes when the cells were cultured at $37^{\circ} \mathrm{C}$ for 2 days, which was definitely higher than cells cultured at $33^{\circ} \mathrm{C}$ in 3 cell lines, WA1, WB6 and BQ1. However, it decreased approximately 31 to $56 \%$ with in vitro passage, and levels of urea were under the lowest OD value of this analytic method.

\section{Telomerase activity}

Telomerase activity was weakly expressed in normal rat hepatocyte, and the level of its activity increased approximately 10 times in all four immortalized cell lines with higher passages (Figure 7).

\section{Lack of anchorage independent growth}

In soft agar assay, the four cell lines did not show any ability to form macroscopically visible colonies, but Hep G2 formed colonies at a rate of $2.2 \pm 0.5 \%$ cloning efficiency.

\section{Discussion}

In this study, we demonstrated that $\mathrm{CIH}$ have low levels of liver-specific functions, compared to primary hepatocytes, and these functions decreased more with in vitro passage. Analysis of liver-specific functions was carried out under the condition that can maintain viability of hepatocytes with retention of liver functions for a relatively long period by use of modified Chees medium and a collagen-based substrate, Vitrogen (Waxman, 1990). Even with this method, dedifferentiation of $\mathrm{ClH}$ cannot be avoided, and it is likely to be caused by progressive 
Table 2. Albumin secretion and urea production in four immortalized hepatocyte lines with lower and higher passage

\begin{tabular}{|c|c|c|c|c|c|}
\hline \multirow[t]{2}{*}{ Cell line } & & \multicolumn{2}{|c|}{$\begin{array}{c}\text { Albumin } \\
\text { (ng/24h/10 } 10^{6} \text { cells) }\end{array}$} & \multicolumn{2}{|c|}{$\begin{array}{c}\text { Urea } \\
\text { (ng/h/106 cells) }\end{array}$} \\
\hline & & $33^{\circ} \mathrm{C}$ & $37^{\circ} \mathrm{C}$ for 2 days & $33^{\circ} \mathrm{C}$ & $37^{\circ} \mathrm{C}$ for 2 days \\
\hline Primary & hepatocytes & not done & $30370 \pm 7940$ & not done & $67267 \pm 22909$ \\
\hline \multirow[t]{2}{*}{ WA1 } & p15 & $1300 \pm 100$ & $3990 \pm 990^{\mathrm{a}}$ & $5547 \pm 1587$ & $13400 \pm 4085^{a}$ \\
\hline & p50 & $780 \pm 28$ & $635 \pm 35^{\mathrm{b}}$ & 0 & $5567 \pm 4945^{\mathrm{b}}$ \\
\hline \multirow[t]{2}{*}{ WB6 } & p19 & $250 \pm 70$ & $715 \pm 64^{a}$ & $2867 \pm 586$ & $5050 \pm 885^{a}$ \\
\hline & p50 & $350 \pm 212$ & $690 \pm 98$ & 0 & $1567 \pm 379^{b}$ \\
\hline \multirow[t]{2}{*}{ BQ1 } & p19 & $735 \pm 21$ & $1640 \pm 184^{a}$ & 0 & $5800 \pm 3724^{a}$ \\
\hline & p50 & $500 \pm 85$ & $575 \pm 49^{b}$ & $1617 \pm 379$ & $1617 \pm 1336$ \\
\hline \multirow[t]{2}{*}{ BV1 } & p20 & $645 \pm 91$ & $895 \pm 64^{a}$ & $4550 \pm 638$ & $6467 \pm 1864$ \\
\hline & p50 & $565 \pm 35$ & $550 \pm 42^{b}$ & $3108 \pm 322$ & $3633 \pm 126^{b}$ \\
\hline
\end{tabular}

Data are mean $\pm \mathrm{SD}$. ${ }^{a}$ significant increase of albumin or urea production at $37^{\circ} \mathrm{C}$ culture, compared to that at $33^{\circ} \mathrm{C}$ culture. ${ }^{b}$ significant decrease of them in the cells with higher passage, compared to that in the cells with lower passage.

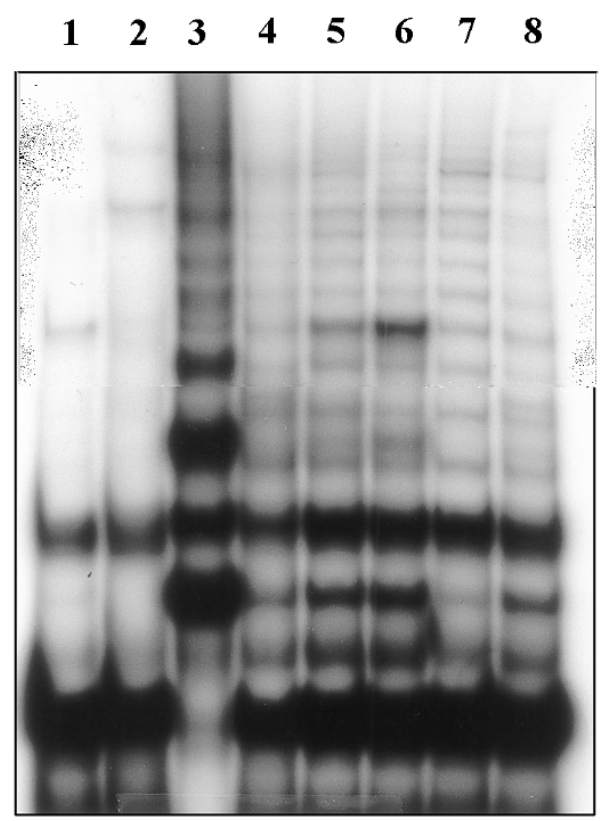

Figure 7. Telomerase activity of the immortalized hepatocyte lines. Telomerase activity is weakly expressed in normal rat hepatocyte, and the level of its activity is about 10 times that of primary hepatocyte in all of four immortalized cell lines with higher passage. Lane 1 to 4 represent primerdimer control, KATO III heated control, KATO III positive control and primary hepatocytes, $2 \mu \mathrm{g}$ of protein respectively. Lane 5 to 8 represent immortalized hepatocyte lines with higher passage, WA1, WB6, BQ1 and BV1, $0.2 \mu \mathrm{g}$ of protein, respectively.

chromosomal damages that occur inevitably during the immortalization step. Normal somatic cells undergo a finite number of replication and ultimately enter a nondividing state called replicative senescence in which the tumor suppressor genes are involved. SV40 T antigen binds to p53 and RB proteins and inhibit normal senescence (Levine, 1990). In our study, the expression pattern of $\mathrm{p} 53$ was similar to that of $\mathrm{T}$ antigen. Wild type p53 has a very short half-life and does not accumulate to levels that can be detected in normal cells (Lane,
1994). Therefore, the p53 bands that were detected on Western blot analysis of this study must have been a non-functioning bound form, which was also confirmed by immunoprecipitation study.

$T$ antigen binding led the cell to overcome normal senescence and divide a few dozens more. In the meantime, telomeres get shortened to the critical length with compulsive and continuous replication due to $T$ antigen, and chromosomal damage can occur (Greider, 1991). In this study, three immortalized hepatocyte lines showed a significant increase of tetraploid and moreover, chromosomal aberrations started to occur with passage in all of the cell lines.

It may be a plausible explanation that the increased $T$ antigen content in higher passage of $\mathrm{ClH}$ leads the cells to keep replicating compulsively and damage chromosomes. However, we cannot offer the exact mechanism why $T$ antigen increases with in vitro passage at the present time. Even with a marked increase of T antigen content in immortalized hepatocyte lines, anchorage independent growth of the cells were not seen, possibly due to its inactivation at non-permissive temperature. At permissive temperature, there was no anchorage independent growth in any cell lines.

In order to be completely immortalized, the cells that overcome normal senescence have to undergo a $2^{\text {nd }}$ step, which is to overcome another $\mathrm{T}$ antigen-induced crisis (Wright et al., 1989). In the second step of immortalization, telomerase activation may be required to stabilize chromosomes with shortened telomeres and permit continuous cell proliferation (Harley et al., 1994). In this study, telomerase activity of immortalized hepatocyte lines was elevated as much 10 times as that of primary hepatocytes. Primary rat hepatocytes also showed a weak telomerase activity in this study. A possible explanation can be the contamination of liver stem cells, which were not removed completely during hepatocyte isolation; otherwise they may normally express telomerase activity (Miura et al., 1998). However, according to our 
results, delayed activation of telomerase may not be enough to stabilize chromosomal damages that occur during the initial step of immortalization.

Woodworth et al. (1988) reported well-functioning, immortalized rat hepatocytes that were established with wild type SV40 T antigen. In murine hepatocytes, it may be possible to get them because they may express telomerase even prior to immortalization and have long telomeres (Kipling et al., 1990), which can protect chromosomes from breakdown that is caused by continuous replications in the presence of $T$ antigen. Even if these speculations are true, liver-specific functions of the cells decreased with in vitro passage as they reported.

$\mathrm{CIH}$ may be a good alternative to normal hepatocytes because they can be cultured almost indefinitely at a permissive temperature, therefore a lot of hepatocytes can be easily obtained. Moreover, liver-specific differentiation is improved when the culture temperature is changed to a nonpermissive temperature, and oncogenicity is less likely to occur at physiologic temperature. However, dedifferentiation of $\mathrm{ClH}$ cannot be avoided with in vitro passage, so it is necessary to develop methods that can enhance liver-specific functions of the cells or avoid chromosomal damages during the immortalization step.

In conclusion, it may be a common phenomenon that immortalized hepatocytes with a gene for tsT become dedifferentiated with in vitro passage. This dedifferentiation may result from marked chromosomal damages that occur with compulsive and continuous replications by increased $T$ antigen content, which sequentially inhibits the function of $\mathrm{p53}$. The mechanism why the content of $\mathrm{T}$ antigen increases with in vitro passage in $\mathrm{ClH}$ remains to be elucidated.

\section{Acknowledgements}

We express our deep gratitude to Dr. P. S. Jat at the Ludwig Institute of Cancer Research, London, UK for kindly providing a cell line producing ecotropic recombinant retrovirus containing a temperature-sensitive mutant of SV40 large T antigen and neomycin phosphotransferase.

\section{References}

Brown, P. C. and Papaconstantinou, J. (1979) Coordinated modulation of albumin synthesis and mRNA levels in cultured hepatoma cells by hydrocortisone and cyclic AMP analogs. $J$. Biol. Chem. 254: 9379-84

Chou, J. Y. (1983) Temperature-sensitive adult liver cell line dependent on glucocorticoid for differentiation. Mol. Cell. Biol. 3: $1013-20$

Clayton, D. F. and Darnell, J. E. Jr. (1983) Changes in liver- specific compared to common gene transcription during primary culture of mouse hepatocytes. Mol. Cell. Biol. 3:1552-61

Clayton, D. F., Weiss, M. and Darnell, J. E. Jr. (1985) Liverspecific RNA metabolism in hepatoma cells: variations in transcription rates and mRNA levels. Cell Biol. 5: 2633-41

Dich, J., Vind, C. and Grunnet, N. (1988) Long-term culture of hepatocytes: effect of hormones on enzyme activities and metabolic capacity. Hepatology 8: 39-45

Fox, I. J., Roy Chowdhury, N., Gupta, S., Kondapalli, R., Schilsky, M., Stockert, R. J. and Roy Chowdhury, J. (1995) Conditional Immortalization of Gunn rat hepatocytes: an ex vivo model for evaluating methods for bilirubin-UDP-glucuronosyltransferase gene transfer. Hepatology 21: 837-46

Greider, C. W. (1991) Chromosome first aid. Cell 67: 645-7

Guguen-Guillouzo, C. and Guillouzo, A. (1983a) Modulation of functional activities in cultured rat hepatocytes. Mol. Cell. Biol. 53/54: 35-56

Guguen-Guillouzo, C., Clement, B., Baffet, G., Beaumont, C., Morel-Chany, E., Glaise, D. and Guillouzo, A. (1983b) Maintenance and reversibility of active albumin secretion by adult rat hepatocytes co-cultured with another liver epithelial cell type. Exp. Cell Res. 143: 47-54

Harley, C. B., Kim, N. W., Prowse, K. R., Weinrich, S. L., Hirsch, K. S., West, M. D., et al. (1994) Telomerase, cell immortality and cancer. Cold Spring Harb. Symp. Quant. Biol. 59: 307-15

Jat, P. S. and Sharp, P. A. (1989) Cell lines established by a temperature-sensitive simian virus 40 large T-antigen gene are growth restricted at the nonpermissive temperature. Mol. Cell. Biol. 9: 1672-81

Kim, N. W., Piatyszek, M. A., Prowse, K. R., Harley, C. B., West, M. D., Ho, P. L. C., Coviello, G. M., Wright, W. E., Weinrich, S. L. and Shay, J. W. (1994) Specific association of human telomerase activity with immortal cells and cancer. Science 266: 2011-15

Kipling, D. and Cooke, H. J. (1990) Hypervariable ultra-long telomeres in mice. Nature 347: 400-2

Kowalski-Saunders, P. W. J., Winwood, P. J., Arthur, M. J. P. and Wright, R. (1992) Reversible inhibition of albumin production by rat hepatocyte maintained on a laminin- rich gel in response to secretory products of Kupffer cells and cytokines. Hepatology 16: 733-41

Lane, D. P. (1994) The regulation of p53 function: Steiner Award Lecture. Int. J. Cancer 57: 623-7

Levine, A. J. (1990) Tumor suppressor genes. BioEssays 12: 60-6

Macpherson, I. and Montagnier, L. (1964) Agar suspension culture for the selective assay of cells transformed by polyomavirus. Virology 23: 291-4

Miura, M., Karasaki, Y., Tetsuya, A., Higashi, K., Ikemura, K. and Gotoh, S. (1998) Prompt activation of telomerase by chemical carcinogens in rats detected with a modified TRAP assay. Biochem. Biophys. Res. Commun. 246: 13-9

Morin, O. and Normand, C. (1986) Long-term maintenance of 
hepatocyte functional activity in co-culture: requirements for sinusoidal endothelial cells and dexamethasone. J. Cell Physiol. 129: 103-10

Nakamura, J., Okamoto, T., Schumacher, I. K., Tabei, I., Roy Chowdhury, N., Roy Chowdhury, J. and Fox, I. J. (1997) Treatment of surgically induced acute liver failure by transplantation of conditionally immortalized hepatocytes. Transplantation 15: 1541-7

Rojkind, M., Gatmatian, Z., Mackensen, S., Giambrone, M. A., Ponce, P. and Reid, L. M. (1980) Connective tissue biomatrix: its isolation and utilization for long-term cultures of normal rat hepatocytes. J. Cell Biol. 87: 255-63

Schumacher, I. K., Okamoto, T., Kim, B-H., Roy Chowdhury, N., Roy Chowdhury, J. and Fox, I. J. (1996) Transplantation of conditionally immortalized hepatocytes to treat hepatic encephalopathy. Hepatology 24: 337-43
Seglen, P. O. (1973) Preparation of rat liver cells. III. Enzymatic requirements for tissue dispersion. Exp. Cell Res. 82: 391-398

Waxman, D. J., Morrissey, J. J., Naik, S. and Jauregui, H. O. (1990) Phenobarbital induction of cytochromes P-450. Biochem. J. 271: 113-9

Woodworth, C. D., Kreider, J. W., Mengel, L., Miller, T., Meng, Y. and Isom, H. C. (1988) Tumorigenicity of simian virus 40hepatocyte cell lines: effect of in vitro and in vivo passage on expression of liver-specific genes and oncogenes. Mol. Cell. Biol. 8: 4492-501

Wright, W., Pereira-Smith, O. and Shay, J. (1989) Reversible cellular senescence: implications for immortalization of normal human diploid fibroblasts. Mol. Cell. Biol. 9: 3088-92 